Volume 2 Nomor 2, Desember 2019

E-ISSN: 2655-7347

\title{
ANALISIS EKSISTENSI TANAH AYAHAN DESA ADAT DIBALI DI TINJAU DARI UNDANG-UNDANG NOMOR 5 TAHUN 1960 TENTANG PERATURAN DASAR-DASAR POKOK AGRARIA (STUDI KASUS: DESA TUSAN, KECAMATAN BANJARANGKAN, KABUPATEN KLUNGKUNG, BALI)
}

\author{
Regina \\ (Mahasiswa Program S1 Fakultas Hukum Universitas Tarumanagara) \\ (E-mail: reginaachenn@gmail.com) \\ Hanafi Tanawijaya, S.H., M.H \\ (Corresponding Author) \\ (Dosen Fakultas Hukum UniversitasTarumanagara. Meraih Sarjana Hukum pada Fakultas Hukum \\ Universitas Tarumanagara, Magister Hukum pada Fakultas Hukum Universitas Tarumanagara) \\ (E-mail: hanafitanawijaya@fh.untar.ac.id)
}

\begin{abstract}
In Indonesia there are still customary rights, customary rights are the oldest rights of customary law communities whose existence is recognized in Article 3 of Law Number 5/1960 as long as the reality still exists and does not conflict with national interests. one of the objects of customary rights is customary land. The existence of customary community's customary land is spread throughout Indonesia, including Bali. Bali is still very strong in customs and culture so that it has many customary law communities who have customary land in each region in Bali. one of them is AYDS land which is located in the Tusan village area, banjarangkan sub-district, klungkung regency, bali. is land that cannot be bought and cannot be certified because it is land with the community in Tusan Village. but someone named I Ketut Sotong said that he had a certificate of ownership of the land which at the time the land was occupied by $\mathrm{Ni}$ Wayan Rosih who was a resident of Tusan village. therefore this research uses a type of normative legal research methods with a legal approach. This research will examine further the existence of customary land namely AYDS in terms of law number 5 of 1960.
\end{abstract}

Keywords: Castom, Castomary Law, Agrarian Law, AYDS. 
Volume 2 Nomor 2, Desember 2019

E-ISSN: 2655-7347

\section{PENDAHULUAN}

\section{A. Latar Belakang}

Indonesia merupakan salah satu negara yang memiliki wilayah yang sangat luas di dunia luas negara Indonesia adalah $5.193 .250 \mathrm{~km}^{2}$ yang mencakup seluruh daratan dan lautan. ${ }^{1)}$ Oleh karena itu dengan begitu luasnya Indonesia maka terdapat beraneka ragam kekayaan sumber daya alam yang melimpah karena begitu besar pemanfaatan sumber daya alam, maka terdapat hak menguasai Negara agar sumber daya alam dapat terpelihara dan dilindungi dengan baik untuk menghindari adanya penyalahgunaan oleh pihak-pihak yang tidak bertanggungjawab, hak menguasai negara tersebut dimuat dalam Pasal 33 Ayat (3) UUD 1945.

Pada tahun 1960 dibentuk Undang-Undang Nomor 5 Tahun 1960 Tentang Peraturan Dasar Pokok-Pokok Agraria atau yang selanjutnya disebut dengan UUPA sebagai perpanjangan dari Pasal 33 Ayat (3) UUD 1945 maka terjadi perubahan signifikan dalam hukum agraria di Indonesia, terutama di bidang pertanahan, yang kita sebut hukum tanah, yang dikalangan pemerintah dan umum kenal sebagai hukum agraria. ${ }^{2}$ UUPA mengakui dan dibuat berdasarkan hukum adat disertai dengan unsur-unsur agama yang berlaku di Indonesia seperti yang dimuat dalam Pasal 5 UUPA dalam hukum adat juga dikenal istilah hak ulayat, yang merupakan hubungan antara masyarakat hukum adat dengan tanah yang berada di wilayahnya hak ulayat serta hak-hak serupa juga diakui keberadaan nya sebagaimana dimuat dalam Pasal 3 UUPA

Hukum adat itu sendiri sering diibaratkan dengan adat atau budaya masyarakat setempat di suatu daerah. Mungkin tidak banyak masyarakat umum

\footnotetext{
1) Chusnul Tri Judianto "Spaceborne AIS: Teknologi Satelit LAPAN-A2 Untuk Pengawasan Wilayah Maritim Indonesia”, Sosialita, Volume 11 Nomor 1 Maret 2016, hal 1.

2) Muhammad Bakri, Hak Menguasai Tanah Oleh Negara: Paradigma Baru Untuk Reformasi Agraria, Cetakan ke-1. (Yogyakarta: Citra Media, 2007), hal. 35.
} 
Volume 2 Nomor 2, Desember 2019 E-ISSN: $2655-7347$

tahu bahwa hukum adat sudah menjadi bagian yang tidak terpisahkan dari sistem hukum nasional Indonesia. Dalam hukum adat, ada komunitas hukum adat yang merupakan unit komunitas dengan pola perilaku yang sama, di mana perilaku tumbuh dan dimanifestasikan oleh masyarakat, dari pola itu, aturan diterapkan untuk mengatur asosiasi kehidupan. Hukum yang hidup, tumbuh dan berkembang di setiap masyarakat manusia, tidak peduli seberapa sederhana atau sekecil apa pun masyarakat itu, tetap tercermin. Setiap masyarakat, setiap orang memiliki budaya mereka sendiri dengan gaya dan karakteristik mereka sendiri. Setiap komunitas, setiap orang memiliki cara berpikir mereka sendiri, demikian pula halnya dengan hukum adat. Hukum adat hidup, tumbuh dan berkembang sesuai dan dengan masyarakat Indonesi. Dalam masyarakat hukum adat dikenal adanya hak ulayat.

Di berbagai tempat tanah hak ulayat mempunyai nama-namanya sendiri. Di Ambon disebut pertuanan, di Kalimantan disebut Panyampeto, di Bali dikatakan sebagai Prabumian, Sulawesi Selatan disebut Limpo dan di Minangkabau disebut Ulayat serta Wewengkon untuk sebutan di Jawa. Hubungan hak ulayat dengan warga masyarakat hukum adat bersifat kesatuan. Hak ulayat dengan hak perorangan bersifat menguncup mengembang bertimbal-balik tiada hentinya. Makin kuat hak perorangan maka makin lemahlah hak-hak kemasyarakatan.

Keberadaan tanah ulayat masyarakat hukum adat tersebar di seluruh wilayah Indonesia, tidak terkecuali di Bali. Bali yang masih sangat kental adat dan budayanya sehingga memiliki banyak masyarakat hukum adat yang mempunyai tanah ulayat pada masing-masing wilayah Desa Pakraman di Bali 
Volume 2 Nomor 2, Desember 2019

E-ISSN: 2655-7347

yang disebut dengan tanah milik desa atau tanah prabumian. ${ }^{3}$ ) tanah prabumian tersebut terdapat 4 jenis yaitu: ${ }^{4)}$

1. Tanah Desa, yaitu tanah yang dipunyai, yang biasa didapati melalui usaha-usaha pembelian atau usaha lainnya.

2. Tanah Laba Pura, yaitu tanah (yang dulunya milik desa atau dikuasasi desa) yang khusus digunakan untuk keperluan pura.

3. Tanah Pekarangan Desa (PKD) adalah merupakan tanah yang dikuasai oleh desa yang diberikan kepada karma desa untuk mendirikan rumah dimana rumah tersebut biasanya dibangun dalam ukuran tertentu dan hampir sama di setiap keluarga.

4. Tanah Ayahan Desa Adat (AYDS), yaitu tanah yang dikuasai atau dimiliki oleh desa yang penggarapannya diberikan kepada masingmasing krama desa disertai hak menikmati hasilnya.

Tanah Ayahan Desa Adat atau selanjutnya disebut sebagai AYDS, terdiri dari kata ayahan berasal dari kata ngayah yang berarti melakukan pekerjaan tanpa upah, ngayah merupakan kewajiaban sosial masyarakat bali yang dilaksanakan secara gotong royong dengan hati yang tulus ikhlas baik di banjar maupun ditempat suci. Dalam suatu desa adat Tusan didalamnya terdapat banjar adat, desa Tusan merupakan desa adat yang mana didalamnya terdapat 4 (empat) banjar yang terdiri dari banjar adat tusan tangin, banjar adat tusan kawan, banjar adat tusan kaler, banjar adat tusan Sema Agung. Keseluruhan banjar adat tersebut termasuk bagian dari desa adat di Tusan.

AYDS merupakan tanah yang diberikan pemerintah kepada desa adat yang kemudian tanah tersebut diberikan kepada warga setempat untuk dikelola

3) Made Oka Cahyadi Wiguna, "Pengaruh Eksistensi Masyarakat Hukum Adat Terhadap Penguasaan Tanah Prabumian Berdasarkan Konsepsi Komunalistik Religius di Bali”, Jurnal Hukum Novelty, Volume 7 Nomor 2 Tahun 2016, hal. 184.

4) I Made Suasthawa Dharmayuda, Desa Adat, Kesatuan Masyarakat Hukum Adat Bali Propinsi Bali, Cetakan Ke-1. (Denpasar: Upada Sastra, 2011), hal. 136. 
Volume 2 Nomor 2, Desember 2019

E-ISSN: 2655-7347

bersama-sama. Setiap warga yang menempati tanah AYDS tidak dapat menguasai tanah itu sebagai hak milik melainkan hanya sebatas hak pakai saja. Sehingga tidak dapat dilakukan penyertifikatan bagi AYDS karena bukan hak milik perorangan oleh karena itu AYDS tidak dapat di jual belikan kepada orang lain karena AYDS dianggap sebagai tanah milik desa adat.

Dalam Kasus antara I Ketut Sotong dengan Ni Wayan Rosih pada mulanya I Ketut Sotong mempunyai suatu tanah di Desa Tusan yang berstatus Hak Milik. Namun tanpa sepengetahuan I Ketut Sotong tanah dan bangunan diatas nya di tempati oleh Namun Ni Wayan Rosih dengan alasan bahwa tanah tersebut adalah tanah adat yaitu tanah AYDS dimana tanah itu telah ditempati oleh nya secara turun temurun sejak tahun 1957 namu I Ketut Sotong mengatakan bahwa tanah itu didapat nya dari hasil jual beli secara sah antara I Ketut Sotong dengan I Made Pasar dan I Ketut Sotong mempunyai bukti Sertifikat Hak Milik serta Akta Jual Beli Tanah tersebut dan bukti pembayaran pajak terhadap tanah tersebut.

Dalam kejadian ini I Ketut Sotong merasa sangat dirugikan, ia sudah beberapa kali menghubungi $\mathrm{Ni}$ Wayan Rosih untuk menyelesaikan permasalahan tersebut dan telah melakukan berbagai upaya namun tidak mendatangkan hasil sehingga I Ketut Sotong mengajukan gugatan perbuatan melawan hukum kepada Ni Wayan Rosih.

Menurut pertimbangan Pengadilan Negeri Semapura dan Pengadilan Tinggi Denpasar bahwa akta jual beli yang dimiliki oleh I Ketut Sotong adalah sah dan menyatakan bahwa tanah tersebut sah milik oleh I Ketut Sotong karena dilakukan sesuai dengan prosedur-prosedur jual beli, namun menurut pertimbangan Mahkamah Agung bahwa tanah tersebut adalah tanah AYDS, dimana tanah tersebut memang tidak dapat dilakukan jual beli sehingga akta jual beli tanah yang di miliki I Ketut Sotong adalah tidak sah. 
Volume 2 Nomor 2, Desember 2019 E-ISSN: $2655-7347$

Oleh karena itu, berdasarkan uraian diatas maka Penulis tertarik mengadakan penelitian lebih lanjut mengenai masalah tersebut dengan judul ANALISIS EKSISTENSI TANAH AYAHAN DESA ADAT DI BALI DI TINJAU DARI UNDANG-UNDANG NOMOR 5 TAHUN 1960 TENTANG PERATURAN DASAR POKOK-POKOK AGRARIA (Studi Kasus di Desa Tusan, Kecamatan Banjarangkan, Kabupaten Klungkung, Bali)

\section{B. PerumusanMasalah}

Setelah diuraikan topik dan masalah serta bukti yang mendukung masalah tersebut. ${ }^{5)}$ Maka Penulis merumuskan permasalahan yang akan dibahas dalam penelitian ini yaitu: Bagaimana Eksistensi Tanah Ayahan Desa Adat berdasarkan Undang-Undang Nomor 5 Tahun 1960 Tentang Peraturan Dasar Pokok-Pokok Agraria?

\section{Metode Penelitian}

1. Jenis Penelitian

Jenis penelitian dalam penelitian ini yaitu penelitian hukum normatif. Penelitian hukum normatif adalah penelitian hukum yang menempatkan hukum sebagai sebuah bangunan sistem norma. Sistem norma yang artinya tentang prinsip, norma, aturan hukum dan peraturan, putusan pengadilan, perjanjian dan doktrin. ${ }^{6}$ )

Penulis menggunakan pendekatan Undang-Undang, pendekatan Undang-Undang adalah penggunaan Undang-Undang dan peraturan

5) Mukti Fajar Nur Dewata dan Yulianto Achmad, Dualisme Penelitian Hukum Normatif dan Empiris, (Yogyakarta: Pustaka Pelajar, 2010), hal. 87.

6) Ibid., hal. 34. 
Volume 2 Nomor 2, Desember 2019 E-ISSN: 2655-7347

yang dilakukan karena Undang-Undang adalah titik fokus penelitian. Pendekatan undang-undang ini mengacu pada Undang-Undang Nomor 5 Tahun 1960 tentang Peraturan Dasar Pokok-Pokok Agraria

2. Jenis Data

Jenis data yang penulis gunakan dalam penelitian ini adalah data sekunder. Data sekunder atau dikenal sebagai bahan hukum. Bahan hukum dari berbagai literatur yang dikelompokkan menjadi : ${ }^{7}$

a. Bahan hukum primer, Peter Mahmud Marzuki mengatakan bahwa bahan hukum primer adalah bahan hukum yang otoritatif, artinya memiliki otoritas. Bahan hukum utama dalam penelitian ini adalah Undang-Undang Nomor 5 Tahun 1960 tentang Peraturan Dasar Pokok-Pokok Agraria

b. Bahan hukum sekunder, yaitu bahan hukum yang menjelaskan bahan hukum primer yang dapat berupa buku teks, jurnal, surat kabar dan berita internet.

c. Bahan hukum tersier, juga merupakan bahan hukum yang dapat menjelaskan materi hukum primer dan material hukum sekunder, dalam bentuk kamus, ensiklopedia, kamus dan lainlain.

3. Teknik Pengumpulan Data

Pengumpulan data yang digunakan dalam penelitian ini dilakukan dengan 2 (dua) cara yaitu studi pustaka dan wawancara terhadap pihak-pihak yang bersangkutan mengenai permasalahan yang diteliti oleh Penulis.

4. Teknik Pengolahan Data

Dalam penelitian hukum normatif, pengelolahan bahan dengan melakukan kegiatan secara sistematis terhadap bahan hukum tertulis.

\footnotetext{
7) Ibid., hal. 157.
} 
Volume 2 Nomor 2, Desember 2019

E-ISSN: 2655-7347

Dalam hal ini pengolahan bahan dilakukan dengan cara memilih data sekunder atau bahan hukum, kemudian mengklasifikasikan menurut klasifikasi bahan hukum dan menyusun hasil penelitian secara sistematis. Tentu saja hal ini dilakukan secara logis, artinya ada hubungan dan hubungan antara bahan hukum uang satu dengan yang lainnya untuk menemukan gambaran dari hasil penelitian. ${ }^{8)}$

5. Teknik Analisis Data

Teknik analisis data dalam penelitian ini bersifat preskriptif, yaitu untuk memberikan argumen untuk hasil penelitian yang telah dilakukan. Argumen di sini dilakukan oleh peneliti untuk memberikan preskriptif atau penilaian benar atau salah atau apa yang harus sesuai dengan hukum tentang fakta atau peristiwa hukum dari hasil penelitian. ${ }^{9)}$

\section{PEMBAHASAN}

\section{A. Kasus Penyalahgunaan AYDS}

Ni Wayan Rosih menempati sebidang tanah di Desa Tusan yang telah ditempati secara turun temurun kurang lebih sejak tahun 1957 dan tanah yang ditempatinya merupakan tanah AYDS yaitu tanah adat yang tidak memiliki bukti otentik bagi pihak yang menguasainya karena tanah tersebut tidak dapat disertifikatkan dan tidak dapat pula dijual belikan.

Kemudian Ni Wayan Rosih diminta untuk pindah dari tanah yang ia tempati oleh I Ketut Sotong karena ia mengakui bahwa tanah yang ditempati Ni Wayan Rosih saat ini telah dibelinya dari I Made Pasar secara sah dengan Sertifikat Hak Milik Nomor 657/Desa Tusan atas nama I Ketut Sotong dengan luas $1200 \mathrm{~m}^{2}$ (seribu dua ratus meter persegi) sebagaimana akta jual beli tanggal

\footnotetext{
8) Ibid., hal. 181.

9) Ibid., hal 184.
} 
Volume 2 Nomor 2, Desember 2019 E-ISSN: 2655-7347

13 Februari tahun 2006 Nomor 30/2006 yang telah dilakukan dihadapan Notaris/PPAT bernama I Gusti Nyoman Rupini. Jual beli antara kedua belah pihak tersebut terlaksana tanpa hambatan atau gangguan dari pihak manapun.

Namun Ni Wayan Rosih tetap menolak permintaan I Ketut Sotong dan tetap menempati tanah tersebut. Sehingga I Ketut Sotong merasa dirugikan akan hal tersebut dan telah melakukan upaya-upaya untuk meminta agar Ni Wayan Rosih tidak menempati tanah tersebut namun tidak membawa hasil sama sekali sehingga I Ketut Sotong (Penggugat) mengajukan gugatan melawan hukum kepada Ni Wayan Rosih (Tergugat) di Pengadilan Semarapura.

\section{Putusan Pengadilan Negeri Semarapura Nomor 37/PDT.G/2017/PN. Srp}

Bahwa penggugat bernama I Ketut Sotong mempunyai sebidang tanah dengan Sertifikat Hak Milik Nomor 657/Desa Tusan yang penggugat beli dari I Made Pasar dan jual beli tersebut dan dilaksanakan dihadapan Notaris/PPAT bernama I Gusti Nyoman Rupini dan dimuatkan dalam akta jual beli.

Namun pada tanggal 13 Februari 2006 Penggugat baru mengetahui bahwa tanah yang dibelinya tersebut di tempati oleh tergugat yang bernama Ni Wayan Rosih, penggugat telah meminta tergugat untuk pindah namun tergugat menolak permintaan penggugat. Kemudian penggugat merasa dirugikan karena dihitung sejak 2006 hasil tanah tersebut setiap tahun nya menghasilkan Rp1.000.000,00 (satu juta rupiah) dan menuntut tergugat untuk melakukan ganti rugi sebesar Rp1.000.000,00 (satu juta rupiah) setiap tahunnya terhitung sejak tahun 2006 dan sampai tergugat menyerahkan tanah tersebut.

Namun Tergugat dalam hal ini mengajukan gugatan balik karena penggugat telah melakukan transaksi atas jual beli tanah yang berstatus AYDS sehingga penggugat telah melakukan perbuatan melawan hukum.

Dan berdasarkan bukti-bukti yang dilampirkan serta saksi yang disertakan oleh para Penggugat dan Tergugat maka hakim mempertimbangkan bahwa: 
Volume 2 Nomor 2, Desember 2019 E-ISSN: 2655-7347

Namun Tergugat dalam hal ini mengajukan gugatan balik karena penggugat telah melakukan transaksi atas jual beli tanah yang berstatus AYDS sehingga penggugat telah melakukan perbuatan melawan hukum.

Dan berdasarkan bukti-bukti yang dilampirkan serta saksi yang disertakan oleh para Penggugat dan Tergugat maka hakim mempertimbangkan bahwa:

1. Bahwa berdasarkan pertimbangan hakim akta jual beli yang dibuat oleh I Ketut Sotong telah sah secara formil sahnya suatu akta otentik, yaitu:

a. Akta tersebut dibuat di hadapan Pejabat yang berwenang dalam hal ini I Gusti Nyoman Rupini,S.H selaku Pejabat Pembuat Akta Tanah (PPAT).

b. Akta tersebut dihadiri oleh para pihak yang membuat perjanjian yaitu I Made Pasar sebagai Penjual dan I Ketut Sotong (Penggugat) sebagai Pembeli;

c. Para pihak selaku Penjual dan Pembeli tersebut telah dikenalkan kepada Pejabat;

d. Pembuatan akta tersebut dihadiri oleh 2 (dua) orang saksi yaitu I Gusti Made Oka Darmayasa dan Drs. Wayan Semadiasa yang ikut menandatangani akta tersebut;

e. Pada bagian awal akta tersebut telah dijelaskan identitas Pejabat, para pihak dan saksi;

2. Bahwa selanjutnya Majelis Hakim akan mempertimbangkan Akta Jual Beli Nomor 30/2006 tanggal 13 Februari 2006 tersebut telah sah secara materiil artinya apakah isi dalam akta tersebut telah memenuhi syaratsyarat sahnya perjanjian sebagaimana diatur dalam ketentuan Pasal 1320 KUHPerdata, yaiitu ada kata sepakat antara para pihak, cakap para pihak, ada hal-hal tertentu dan adanya sebab/causa yang halal.

3. bahwa seseorang dikatakan cakap untuk melakukan perbuatan hukum apabila sudah dewasa serta tidak sedang di bawah pengampuan atau 
Volume 2 Nomor 2, Desember 2019

E-ISSN: 2655-7347

tidak terganggu ingatannya; bahwa dalam Akta Jual Beli Nomor 30/2006, Tanggal 13 Februari 2006 diperoleh fakta bahwa pada saat melakukan perjanjian jual beli tanah sengketa tersebut, I Made Pasar sudah berusia 48 (empat puluh delapan) tahun dan I Ketut Sotong (Penggugat) sudah berusia 52 (lima puluh dua) tahun dan keduanya sedang tidak di bawah pengampuan ataupun terganggu ingatannya terbukti baik I Made Pasar maupun I Ketut Sotong (Penggugat) menandatangani dengan baik Akta Jual Beli

4. Bahwa berdasarkan pertimbangan-pertimbangan di atas maka dapat disimpulkan para pihak yang membuat Perjanjian Jual Beli sebagaimana Akta Jual Beli Nomor 30/2006, Tanggal 13 Februari 2006 adalah cakap dan wenang secara hukum;

5. bahwa berdasarkan pertimbangan tersebut maka terbukti antara I Made Pasar selaku penjual dan I Ketut Sotong (Penggugat) selaku Pembeli telah sepakat tentang barang dan harga yang akan diperjualbelikan yaitu barangnya berupa sebidang tanah seluas $1.200 \mathrm{~m}^{2}$ yang terletak di Desa Tusan, Kecamatan Banjarangkan, Kabupaten Klungkung dengan harga jual beli sebesar Rp. 25.000.000,00 (dua puluh lima juta rupiah).

Setelah berbagai pertimbangan yang telah hakim lakukan maka berikut merupakan amar putusan hakim:

1. Mengabulkan gugatan Penggugat Konpensi/Tergugat Rekonpensi untuk sebagian;

2. Menyatakan tanah sengketa sebagaimana Sertifikat Hak Milik Nomor 657/Desa Tusan, Surat ukur tanggal 27 Mei 1998, Nomor 921/1998, Luas $1.200 \mathrm{~m} 2$ (seribu dua ratus meter per segi) atas nama I Ketut Sotong adalah sah milik Penggugat;

3. Menyatakan Tergugat telah melakukan Perbuatan Melawan Hukum; 
Volume 2 Nomor 2, Desember 2019 E-ISSN: $2655-7347$

4. Menghukum Tergugat atau siapapun juga yang menguasai tanah sengketa dan/atau memperoleh hak dari padanya untuk menyerahkan tanah sengketa dalam keadaan kosong atau membongkar segala bangunan yang ada di atasnya secara sukarela atau apabila diperlukan dengan bantuan pihak kepolisian;

5. Menolak gugatan Penggugat Konpensi/Tergugat Rekonpensi untuk selain dan selebihnya.

Dalam Rekonpensi :

- Menolak gugatan Penggugat Rekonpensi/Tergugat Konpensi untuk seluruhnya;

Dalam Konpensi dan Rekonpensi:

- Menghukum Penggugat Rekonpensi/Tergugat Konpensi untuk membayar biaya yang timbul dari perkara ini sejumlah Rp 1.826.000,00 (satu juta delapan ratus dua puluh enam ribu rupiah).

\section{Putusan Pengadilan Tinggi Denpasar Nomor 34/PDT/2018}

Kemudian Ni Wayan Rosih mengajukan permohonan banding ke Pengadilan Tinggi Denpasar namun Majelis Hakim Pengadilan Tinggi Denpasar menguatkan putusan Majelis Hakim Pengadilan Negerti Semarapura, dengan amar putusan hakim sebagai berikut:

1. Menerima permohonan banding dari Pembanding semula Tergugat;

2. Menguatkan putusan Pengadilan Negeri Semarapura tanggal 25 Januari 2018 Nomor : 37/ Pdt.G / 2017 / PN. Srp yang dimohonkan banding tersebut;

3. Menghukum Tergugat/Pembanding untuk membayar seluruh biaya perkara yang timbul dalam kedua tingkat pengadilan yang di tingkat banding ditetapkan sebesar Rp. 150.000,00 (seratus lima puluh ribu rupiah). 
Volume 2 Nomor 2, Desember 2019 E-ISSN: 2655-7347

\section{Putusan Pengadilan Mahkamah Agung Nomor 2481 K/PDT/2018}

Atas hasil putusan Pengadilan Negeri dan Pengadilan Tinggi yang belum dirasa cukup oleh tergugat, maka tergugat mengajukan gugatan ke Mahkamah Agung dimana tergugat pada saat ini sebagai Pemohon Kasasi dan tergugat sebagai Termohon Kasasi.

Berdasarkan alasan-alasan kasasi yang diajukan maka Mahkamah Agung berpendapat bahwa:

1. berdasarkan surat bukti Tergugat dan keterangan saksi-saksi Tergugat dihubungkan dengan hasil sidang di tanah objek sengketa ternyata bahwa tanah objek sengketa adalah tanah AYDS (Ayahan Desa Adat), yang diatasnya berdiri rumah Tergugat yang ditempati secara turun temurun

2. Bahwa tanah AYDS (Ayahan Desa Adat) tidak boleh disertifikatkan dan tidak boleh dijualbelikan sehingga pensertifikatan dan penghibahan kepada I Made Pasar selanjutnya penjualan kepada Penggugat telah melanggar aturan tanah AYDS (Ayahan Desa Adat);

3. Bahwa pengggugat tidak dapat dilindungi sebagai pembeli beriktikad baik karena seharusnya mengetahui objek sengketa di sebelah Timur Pura yang berdiri rumah Tergugat yang diitempati keluarga Tergugat secara turun temurun adalah tanah yang tidak dapat dijualbelikan sehingga patut dikualifikasi pembeli yang tidak berhati-hati.

Oleh karena itu berdasarkan alasan-alasan dan pertimbangan Mahkamah Agung, berikut merupakan amar putusan Mahkamah Agung:

Dalam Eksepsi:

- Menolak eksepsi Tergugat seluruhnya;

Dalam Konvensi:

- Menolak gugatan Penggugat seluruhnya; 
Volume 2 Nomor 2, Desember 2019 E-ISSN: $2655-7347$

Dalam Rekonvensi:

1. Mengabulkan gugatan Penggugat Rekonvensi/Tergugat Konvensi untuk sebagian;

2. Menyatakan Tergugat Rekonvensi/Penggugat Konvensi yang telah melakukan transaksi jual beli atas tanah AYDS (Ayahan Desa Adat) Desa Pekraman Tusan adalah perbuatan melawan hukum;

3. Menyatakan Sertifikat Hak Milik Nomor 657/Desa Tusan adalah cacat hukum dan tidak berlaku mengikat;

4. Menolak gugatan Penggugat Rekonvensi/Tergugat Konvensi untuk selain dan selebihnya;

Dalam Konvensi dan Rekonvensi:

- Menghukum Termohon Kasasi untuk membayar biaya perkara dalam semua tingkat peradilan yang dalam tingkat kasasi ini ditetapkan sejumlah Rp500.000,00 (lima ratus ribu rupiah)

\section{B. Eksistensi Tanah Ayahan Desa Adat Bagi Masyarakat Adat Desa Tusan, Kecamatan Banjarangkan, Kabupaten Klungkung, Bali Menurut UUPA}

Tanah merupakan sesuatu yang memiliki arti penting bagi masyarakat karena sifat tanah yang fungsional seperti dapat dijadikan tempat permukiman, tempat usaha serta merupakan salah satu faktor produksi yang sangat penting bagi masyarakat. Selain itu tanah dinilai sebagai suatu benda berharga karena sifat nya yang permanen dan tidak mudah berubah, tanah juga dapat dijadikan investasi di masa yang akan datang. Bagi sebagaian orang beranggapan bahwa tanah adalah suatu harta yang mempunyai sifat kekal dan dapat dicadangkan untuk kehidupan baik bagi dirinya dikala hari tua ataupun untuk anak cucu dimasa mendatang sedangkan sebagian orang ada pula yang beranggpan bahwa 
Volume 2 Nomor 2, Desember 2019

E-ISSN: 2655-7347

tanah mengandung nilai-nilai yang tinggi yang harus dihormati. ${ }^{10}$ ) Dengan berkembangnya penduduk, kebutuhan akan tanah semakin meningkat sehingga tanah semakin banyak dikuasai. Keadaan inilah melahirkan hak komunal dari seluruh anggota kelompok, dalam pandangan hukum bahwa hubungan manusia dengan tanah menjadi semakin penting, karena selain hak komunal juga ada hak perorangan. ${ }^{11)}$

Menurut hukum adat, manusia dengan tanahnya mempunyai hubungan kosmis-magis-religius, selain hubungan hukum. Hubungan ini tidak hanya antara individu dengan tanah juga antara sekelompok anggota masyarakat suatu masyarakat hukum adat dalam hubungan hak ulayat. Menurut hukum adat terdapat dua hak atas tanah yaitu hak perorangan atas tanah dan hak menguasai tanah dengan ciri tidak dimiliki secara individual/perorangan yang disebut dengan hak ulayat yang dikuasai oleh masyarakat hukum adat.

Dalam UUPA dan penjelasannya tidak diuraikan kriteria masih ada atau tidaknya suatu hak ulayat, sehingga menimbulkan ketidak jelasan bagi masyarakat bahkan menimbulkan konflik yang berkepanjangan. Oleh karena itu terdapat berbagai pendapat yang merumuskan kriteria keberadaan hak ulayat salah satunya menurut Boedi Harsono menyatakan hak ulayat masih ada apabila:

1. Masih adanya suatu kelompok orang sebagai warga suatu persekutuan hukum adat tertentu, yang merupakan suatu masyarakat hukum adat;

2. Masih adanya wilayah yang merupakan ulayat masyarakat hukum adat tersebut, yang didasari sebagai tanah kepunyaan bersama para warganya

3. Masih adanya penguasaan adat yang pada kenyataannya dan diakui oleh para warga masyarakat hukum adat yang bersangkutan, melakukan kegiatan sehari-hari sebagai pelaksana ulayat.

10) Abdurrachman, Tanya-Jawab Masalah Pertanahan, (Jakarta: Sinar Harapan, 1985), hal. 10.

11) Rosnidar Sembiring, Hukum Pertanahan Adat. (Depok: RajaGrafindo Persada, 2017), hal.5. 
Volume 2 Nomor 2, Desember 2019 E-ISSN: 2655-7347

Kemudian menurut Maria S.W Sumardjono berpendapat bahwa ada tidaknya hak ulayat harus dilihat dalam 3 (tiga) hal, yaitu:

1. Adanya masyarakat hukum adat yang mematuhi ciri-ciri tertentu, sebagai subjek hak ulayat;

2. Adanya tanah/wilayah dengan batas-batas tertentu sebagai labensraum yang merupakan objek hak ulayat; dan

3. Adanya kewenangan masyarakat hukum adat untuk melakukan tindakan-tindakan tertentu.

Hak ulayat merupakan hak yang melekat sebagai kompetensi khas pada masyarakat hukum adat, berupa wewenang/kekuasaan mengurus dan mengatur tanah sisinya, dengan daya berlaku ke dalam dan ke luar. ${ }^{12}$ ) hak ulayat masyarakat hukum adat diakui dalam Pasal 18B ayat (2) UUD 1945 yang berbunyi:

"Negara mengakui dan menghormati kesatuan-kesatuan masyarakat hukum adat serta hak-hak tradisonalnya sepanjang masih hidup dan sesuai dengan perkembangan masyarakat dan prinsip Negara Kesatuan Republik Indonesia, yang diatur dalam Undang-Undang”

Sebagaimana dimuat Pasal 18B ayat (2) UUD 1945 bahwa Negara Indonesia mengakui dan menghormati adanya hak ulayat masyarakat hukum adat dengan mengingat ketentuan bahwa sepanjang hak tersebut masih berlaku dan sesuai dengan pertumbuhan masyarakat yang ada dan tidak bertentangan dengan prinsip-prinsip negara yang termuat dalam Undang-Undang. Di Negara Indonesia seperti desa di Jawa dan Bali, negeri di Minangkabau, dusun dan marga di Palembang dan lain-lain, daerah tersebut mempunyai struktur asli sehingga bersifat istimewa karena itu Negara Indonesia menghormati daerah istimewa tersebut sehingga dalam membuat peraturan negara yang dibuat mengenai daerah tersebut akan meningat hak-hak asal daerah tersebut.

${ }^{12)}$ Maria S.W. Sumardjono, Kebijakan Pertanahan Antara Regulasi dan Implementasi, (Jakarta: Buku Kompas, 2001), hal. 55. 
Volume 2 Nomor 2, Desember 2019 E-ISSN: 2655-7347

Kemudian hak ulayat masyarakat hukum adat juga tercantum Pasal 28I ayat (3) yang berbunyi "identitas budaya dan hak masyarakat tradisional dihormati selaras dengan perkembangan zaman dan peradaban" Semakin berkembangnya zaman maka masyarakat mengenai nilai-nilai dan prinsip-prinsip yang dianut juga mengikuti perkembangan dan dapat berubah sehingga hak ulayat tetap di hormati selama selaras dengan perkembangan zaman.

Selain Pasal 18B ayat (2) dan Pasal 28I ayat (3) UUD 1945 terdapat pula dalam Pasal 6 ayat (2) UU Nomor 39 Tahun 1999 tentang Hak Asasi Manusia (UU HAM) yang menyatakan bahwa "identitas budaya masyarakat hukum adat, termasuk hak atas tanah ulayat dilindungi, selaras dengan perkembangan zaman." Dalam Pasal 6 ayat (2) UU HAM termuat isi Pasal yang tidak jauh berbeda dengan Pasal 28I ayat (3) UUD 1945 hanya saja dalam UU HAM pernyataan hak ulayat lebih spesifik disebutkan secara tegas dalam Pasal nya, sedangkan dalam Pasal 28I ayat (3) UUD 1945 memuat Pasal yang lebih abstrak. Jadi jika di lihat dari dari segi hak asasi manusia maka hak ulayat juga dilindungi keberadaannya.

Bahwa dalam rangka konkretisasi pengakuan hak ulayat oleh UUD dan Undang-Undang lainnya maka oleh pemerintah diterbitkan Peraturan Menteri Dalam Negeri Nomor 52 Tahun 2014 tentang Pedoman Pengakuan Dan Perlindungan Masyarakat Hukum Adat yaitu dalam konteks mengakui dan menghormati kesatuan masyarakat hukum adat dan hak-hak tradisional mereka selama mereka masih hidup dan sesuai dengan perkembangan masyarakat dan prinsip-prinsip Negara Kesatuan Republik Indonesia perlu untuk mengenali dan melindungi masyarakat hukum adat. Berdasarkan hasil wawancara dengan Dr. Hasni, S.H., M.H bahwa tanah ulayat mempunyai hubungan yang sangat erat dengan Pasal 33 ayat (3) UUD 1945 yang berbunyi bahwa:

Bumi, air dan kekayaan alam yang terkandung didalamnya dikuasai oleh negara dan di pergunakan untuk sebesar-besarnya kemakmuran rakyat. 
Volume 2 Nomor 2, Desember 2019 E-ISSN: 2655-7347

Karena hak ulayat mempunyai objek berupa tanah ulayat dan karena objek tanah ulayat berada di wilayah Negara Indonesia maka tanah ulayat merupakan bagian dari Negara Kesatuan Republik Indonesia sehingga dapat dikatakan sebagai objek yang menuju kemakmuran rakyat.

Kemudiann Negara memberikan hak menguasai sebagaiman yang termuat dalam UUPA, Pasal 2 UUPA menyebutkan bahwa:

"Hak menguasai dari Negara tersebut diatas pelaksanaannya dapat dikuasakan kepada daerah-daerah Swatantra dan masyarakatmasyarakat hukum adat, sekedar diperlukan dan tidak bertentangan dengan kepentingan Nasional, menurut ketentuanketentuan Peraturan Pemerintah."

Bahwa setiap warga diberikan hak menguasai dari Negara, sebagaimana yang dimuat dalam UUPA ditetapkan jenis atau hierarki dan hak-hak penguasaan atas tanah dalam Hukum Tanah Nasional kita, yaitu: ${ }^{13)}$

1. Hak Bangsa Indonesia, sebagai hak penguasaan atas tanah yang tertinggi, beraspek perdata dan public

2. Hak Menguasai dari Negara yang merupakan semata-mata beraspek public

3. Hak Ulayat Masyarakat Hukum Adat

a. Hak peroangan/individual, terdiri atas:

1) Hak-hak atas Tanah sebagai hak-hak individual yang semuanya secara langsung maupun tidak langsung bersumber pada Hak Bangsa

2) Wakaf, yaitu Hak Milik yang sudah diwakafkan

3) Hak Jaminan atas Tanah yang disebut Hak Tanggungan

${ }^{13)}$ Boedi Harsono, Hukum Agraria Indonesia, Sejarah Pembentukan Undang-Undang Pokok Agraria, Isi dan Pelaksanaannya. (Jakarta: Djambatan,2003).hal. 26. 
Volume 2 Nomor 2, Desember 2019 E-ISSN: 2655-7347

Dan untuk siapa saja yang dapat meneremia hak menguasai yang diberikan oleh Negara termuat dalam Pasal 9 Ayat (1) UUPA yang menyatakan bahwa:

"hanya warga-negara Indonesia dapat mempunyai hubungan yang sepenuhnya dengan bumi, air dan ruang angkasa, dalam batas-batas ketentuan pasal 1 dan 2"

Kemudian tanah ulayat keberadaannya sangat kuat berdasarkan Pasal 3 UUPA yang berbunyi:

"Dengan mengingat ketentuan-ketentuan dalam Pasal 1 dan 2 pelaksanaan hak ulayat dan hak-hak yang serupa itu dari masyarakatmasyarakat hukum adat, sepanjang menurut kenyataannya masih ada, harus sedemikian rupa sehingga sesuai dengan kepentingan nasional dan Negara, yang berdasarkan atas persatuan bangsa serta tidak boleh bertentangan dengan Undang-Undang dan peraturan-peraturan lain yang lebih tinggi."

Ketentuan Pasal 3 UUPA ini pertama-tama berasal dari pengakuan akan keberadaan hak ulayat dalam hukum agraria yang baru. Seperti diketahui meskipun dalam kenyataannya hak-hak ulayat ada dan berlaku dan juga diperhitungkan dalam keputusan hakim, hak-hak ini tidak pernah secara resmi diakui dalam UU, dengan hasil bahwa dalam mengimplementasikan peraturan agraria hak-hak adat berada di zaman kolonial dulu sering diabaikan.

Karena penyebutan hak-hak ulayat dalam Undang-Undang Pokok Agraria, yang pada dasarnya juga berarti pengakuan terhadap hak-hak tersebut, pada dasarnya hak-hak adat akan dipertimbangkan, selama hak-hak ini masih ada dalam masyarakat hukum yang bersangkutan. Misalnya, dalam memberikan hak atas tanah (misalnya, hak guna usaha) masyarakat hukum dengan perjanjian sebelumnya akan didengar pendapatnya dan akan diberikan "recognitie", yang memang ia memiliki hak untuk menerima sebagai pemegang hak ulayat. 
Volume 2 Nomor 2, Desember 2019 E-ISSN: 2655-7347

Tetapi sebaliknya tidak dapat dibenarkan, jika berdasarkan hak ulayat, masyarakat hukum menghalangi pemberian hak guna usaha, sedangkan pemberian hak di wilayah tersebut benar-benar perlu untuk kepentingan yang lebih luas. Demikian juga, tidak dapat dibenarkan jika masyarakat hukum berdasarkan pada hak-hak adatnya, misalnya menolak untuk membuka hutan skala besar dan teratur untuk melaksanakan proyek-proyek besar dalam konteks implementasi rencana untuk meningkatkan hasil pangan dan pemukiman kembali. Pengalaman juga menunjukkan bahwa pengembangan daerah itu sendiri sering terhambat karena kesulitan mengenai hak ulayat mereka. Ini adalah dasar pemikiran kedua dari ketentuan Pasal 3 UUPA di atas.

Kepentingan masyarakat hukum harus tunduk pada kepentingan nasional dan negara yang lebih luas dan hak ulayat mereka harus dijalankan sesuai dengan kepentingan yang lebih luas itu. Tidak dapat dibenarkan, jika dalam kondisi saat ini suatu masyarakat hukum masih mempertahankan isi dan pelaksanaan hak ulayat secaraa mutlak, seolah-olah terlepas dari hubungannya dengan masyarakat hukum dan wilayah lain di dalam Negara sebagai satu kesatuan. Sikap seperti itu jelas bertentangan dengan prinsipprinsip dasar yang tercantum dalam Pasal 2 dan dalam praktiknya juga akan berakibat pada upaya keras untuk mencapai kemakmuran rakyat secara keseluruhan.

Mengenai Tanah AYDS jika dilihat apakah memenuhi unsur-unsur ada atau tidaknya hak ulayat maka yang pertama yaitu harus ada wilayahnya, tanah AYDS berada di wilayah Desa Tusan dengan luas tanah AYDS kurang lebih sekitar kurang lebih $60.000 \mathrm{~m}^{2}$ (enam puluh ribu meter persegi), kedua yaitu adanya masyarakat hukum adat, tanah AYDS ditempati sejak turun temurun oleh warga Desa Tusan yang berstatus Warga Negara Indonesia dan warga desa yang menempati tanah AYDS tersebut mereka diwajibkan untuk ngayah, sehingga 
Volume 2 Nomor 2, Desember 2019 E-ISSN: $2655-7347$

ada kententuan-kentutan yang harus mereka lakukan karena telah menempati tanah AYDS tersebut, kemduain yang terkahir yaitu adanya Bandesa Adat yang bertugas untuk mengurus segala sesuatu mengenai permasalahan adat yang terjadi. Jadi berdasarkan kenyataan-kenyataan di atas maka Tanah AYDS memenuhi unsur-unsur berlakunya hak ulayat.

Dengan demikian tanah AYDS merupakan tanah ulayat yang merupakan objek dari hak ulayat oleh karena itu merupakan bagian dari wilayah Indonesia sehingga di gunakan untuk kemakmuran rakyat. Sehingga tanah AYDS merupakan tanah yang diberikan hak menguasai oleh Negara berdasarkan Pasal 2 UUPA, tanah AYDS di berikan oleh pemerintah untuk di kuasai oleh desa adat dan kemudian desa adat memberikan tanah itu untuk di kuasai oleh warga desanya namun tidak dapat dimiliki secara perorangan hanya sekedar hak pakai saja dan warga desa tusan berstatus Warga Negara Indonesia sehingga mereka berhak dan sah untuk menguasai tanah tersebut sebagaimana di atur dalam Pasal 9 UUPA. Tanah AYDS juga sudah di tempati secara turuhn temurun artinya sudah ada dan berlaku sejak zaman dahulu oleh karena itu untuk masyarakat yang menempati tanah tersebut mempunyai hak untuk dilindungi keberadaannya dan masyarakat adat tersebut mempunyai hak asasi manusia terhadap tanah yang di tempatinya tersebut karena mengenai hak ulayat juga diatur oleh UU HAM sebagaimana dicantumkan dalam Pasal 6 ayat (2) UU HAM. Sehingga walaupun tanah tersebut tidak di cantumkan kepemilikan nya secara tertulis namun terdapat hak ulayat yang melekat pada masyarakat tersebut, sehingga masyarakat luar tidak bisa langsung merampas hak tersebut, mensertifikatkan atau melakukan jual beli terhadap tanah tersebut. Mengingat kassus Ni Wayan Rosih dan I Ketut Sotong walaupun I Ketut Sotong mempunyai Akta Jual Beli yang sah dan mempunyai sertifikat Hak Milik atas nama I Ketut Sotong terhadap tanah yang di tempati oleh Ni Wayan Rosih, maka Hak Milik tersebut dapat dibatalkan. Mengingat Pasal 18 UUPA, pasal ini 
Volume 2 Nomor 2, Desember 2019 E-ISSN: 2655-7347

merupakan jaminan bagi rakyat mengenai hak-haknya yang menyatakan bahwa "untuk kepentingan umum, termasuk kepentingan bangsa dan Negara serta kepentingan bersama dari rakyat, hak-hak atas tanah dapat dicabut dengan memberi ganti kerugian yang layak dan menurut cara yang diatur dengan Undang-Undang."

Sehingga Hak Milik dari I Ketut Sotong tersebut dapat dibatalkan mengingat tanah yang dimiliki nya tersebut adalah tanah AYDS yang merupakan tanah ulayat yang didalammnya terdapat hak ulayat yang berdasarkan Pasal 3 UUPA yang mengakui keberadaan hak ulayat sepanjang kenyataannya masih ada, Tanah AYDS merupakan tanah ulayat yang masih ada dan masih berlaku sampai saat ini sehingga keberadaannya di akui oleh UUPA yang termuat dalam Pasal 3 UUPA

Mengenai tanah AYDS dapat dikatakan memiliki unusr-unusr berlakunya hak ulayat yaitu pertama jika dilihat dari keberadaan wilayahnya AYDS berada di wilayah Desa Tusan dengan luas tanah AYDS kurang lebih $60.000 \mathrm{~m}^{2}$ (enam puluh ribu meter persegi) yang kedua AYDS di tempati dan dikelola oleh sejumlah warga desa yang berstatus Warga Negara Indonesia Warga desa tusan sudah menempati tanah tersebut sejak turun temurun dari zaman dahulu, mengenai tanah AYDS warga desa diberikan hak pakai untuk mengelolah tanah tersebut sesuai kehendak masing-masing, ketiga mereka melakukan ketentuanketentuan tertentu sebagai kewenangan yaitu mereka berkewajiban untuk ngayah di desa tersebut. Tiap-tiap orang tidak dapat menguasai tanah AYDS secara pribadi karena tanah AYDS merupakan tanah yang dimiliki bersama, demikian juga pula apabila suatu tanah AYDS tidak ada yang menguasai lagi yang disebabkan tidak ada keturunan selanjutnya yang melanjutkan maka tanah tersebut akan di kembalikan ke desa adat dan akan diberikan kembali kepada warga desa yang tidak mempunyai tempat tinggal. 
Volume 2 Nomor 2, Desember 2019

E-ISSN: 2655-7347

Kemudian mengenai AYDS juga di atur dalam Awig-Awig Desa Adat Tusan, Awig-Awig adalah suatu produk hukum dari suatu organisasi tradisional di Bali, yang umumnya dibuat secara musyawarah mufakat oleh seluruh anggotanya dan berlaku sebagai pedoman bertingkah laku dari anggota organisasi yang bersangkutan. Dengan demikian, Awig-Awig adalah patokan-patokan tingkah laku yang dibuat oleh masyarakat berdasarkan rasa keadilan dan rasa kepatutan yang hidup dalam masyarakat yang bersangkutan.

\section{PENUTUP}

\section{A. Kesimpulan}

Tanah AYDS merupakan tanah yang terletak di Desa Tusan, merupakan tanah yang sudah ditempati oleh sekumpulan masyarakat hukum adat sejak zaman leluhur, sehingga tanah AYDS tersebut di wariskan kepada keturunannya dan di tempati secara turun temurun. Tanah AYDS merupakan tanah yang diberikan oleh pemerintah untuk dikuasai oleh desa adat dan kemudian tanah tersebut di berikan hak pakai kepada warga desa tusan sehingga masing-masing orang tidak dapat menguasai nya secara peorangan atau hak milik, karena tanah AYDS merupakan tanah bersama masyarakat adat setempat. Begitu juga apabila orang yang menempati tanah AYDS tidak memiliki keturunan untuk diwariskan dan kemudian meninggal dunia maka tanah tersebut akan dikembalikan kepada desa adat lalu akan diberikan kepada warga desa yang tidak memiliki tempat tinggal.

Tanah AYDS ditempati oleh masyarakat yang masih melakukan kewajibannya yaitu ngayah sebagai sesuatu yang harus dilakukan kepada desa karena telah menempati tanah AYDS. Tanah AYDS memiliki luas sekitar 60.000 $\mathrm{m}^{2}$ (enam puluh ribu meter persegi) yang tiap-tiap warga desa mendapatkan tanah AYDS sekitar $200 \mathrm{~m}^{2}$ (dua ratus meter persegi) $-1000 \mathrm{~m}^{2}$ (seribu meter persegi) dan dikepalai oleh seorang bandesa adat yang bertugas untuk 
Volume 2 Nomor 2, Desember 2019 E-ISSN: 2655-7347

mengayomi serta membantu menyelesaikan apabila terdapat peristiwa-peristiwa yang terjadi di desa adat tersebut. jadi berdasarkan ciri diatas dapat dikatakan bahwa tanah AYDS merupakan tanah ulayat yang mana merupakan hak ulayat masyarakat hukum adat setempat.

Hak ulayat keberadaan nya di akui oleh Hukum Nasional di Indonesia, salah satunya UUPA yang termuat dalam Pasal 3 UUPA. Pasal 3 UUPA menyatakan bahwa sepanjang kenyataannya masih ada dan tidak bertentangan dengan hukum nasional hak ulayat tersebut harus sedemikian rupa yang diutamakan yang sesuai pasal 5 UUPA mengatakan bahwa hukum agraria yang berlaku atas bumi, air dan ruang angkasa ialah hukum adat.

Jadi Tanah yang telah dilaksanakan jual beli antara I Ketut Sotong dan I Made Pasar dengan Sertifikat Hak Milik Nomor 657/Desa Tusan atas nama I Ketut Sotong dilaksanakan dihadapan Notaris/PPAT bernama I Gusti Nyoman Rupini dan dimuatkan dalam akta jual beli mengenai Hak Milik nya harus dibatalkan karena yang disertfikatkan merupakan tanah AYDS yang tidak bisa dijual beli kan dan tidak bisa disertifikatkan oleh karena merupakan tanah ulayat yang tidak bisa dikuasai perorangan dan keberadaannya dilindungi oleh Pasal 3 UUPA.

\section{B. Saran}

Kepada pihak-pihak yang akan membeli tanah berhati-hati terlebih dahulu dalam membeli tanah dan lebih baik langsung melihat keadaan tanah sekitar apakah dalam kondisi baik atau apakah ada yang menempati tanah tersebut dan menelaah leih lanjut mengenai asal usul tanah yang akan dibeli sehingga tidak menimbulkan kerugian bagi dirinya sendiri atau bagi pihak lain dikemudian hari.

Bagi pihak Badan Pertanahan Indpnesia sebelum mengeluarkan sertifikat hak milik lebih baik melakukan penelitian yang lebih teliti terlebih dahulu mengenai kondisi suatu tanah, tidak hanya mengukur luas dan batasbatas tanah tersebut tapi mengetahui pula asal usul tanah tersebut apakah 
Volume 2 Nomor 2, Desember 2019 E-ISSN: 2655-7347

tanah tersebut dapat di lakukan jual beli dan dapat atau tidaknya diterbitkan sertifikat hak milik.

\section{DAFTAR PUSTAKA}

\section{A. Buku-buku}

Abdurrachman. Tanya-Jawab Masalah Pertanahan. (Jakarta: Sinar Harapan, 1985).

Bakri, Muhammad. Hak Menguasai Tanah Oleh Negara: Paradigma Baru Untuk Reformasi Agraria. Cetakan ke-1. (Yogyakarta: Citra Media, 2007).

Dharmayuda Suasthawa, I Made. Desa Adat, Kesatuan Masyarakat Hukum Adat Bali Propinsi Bali. Cetakan Ke-1. (Denpasar: Upada Sastra, 2011). Fajar, Mukti dan Yulianto Achmad. Dualisme Penelitian Hukum Normatif dan Empiris. (Yogyakarta: Pustaka Pelajar, 2010).

Harsono, Boedi. Hukum Agraria Indonesia, Sejarah Pembentukan UndangUndang Pokok Agraria, Isi dan Pelaksanaannya. (Jakarta: Djambatan, 2003).

Sembiring, Rosnidar. Hukum Pertanahan Adat. (Depok: RajaGrafindo Persada, 2017).

Sumardjono, Maria S.W. Kebijakan Pertanahan Antara Regulasi dan Implementasi. (Jakarta: Buku Kompas, 2001).

\section{B. Peraturan Perundang-Undangan}

Indonesia. Undang-Undang Dasar Tahun 1945. Cetakan ke-5 (Jakarta: Kepaniteraan dan Sekretariat Jendral Mahkamah Konstitusi RI. 2016) . Undang-Undang Nomor 5 Tahun 1960 tentang Peraturan Dasar Pokok- Pokok Agraria.

. Undang-Undang Nomor 39 Tahun 1999 tentang Hak Asasi Manusia 
Volume 2 Nomor 2, Desember 2019

E-ISSN: 2655-7347

. Undang-Undang Nomor 6 Tahun 2014 tentang Desa.

. Peraturan Menteri Dalam Negeri Nomor 52 Tahun 2014 tentang

Pedoman Pengakuan Dan Perlindungan Masyarakat Hukum Adat.

\section{Putusan}

Putusan Pengadilan Negeri Semarapura Nomor 37/PDT.G/2017/PN. Srp

Putusan Pengadilan Tinggi Denpasar Nomor 34/PDT/2018

Putusan Pengadilan Mahkamah Agung Nomor 2481 K/PDT/2018

D. Jurnal

Wiguna, Made Oka Cahyadi. "Pengaruh Eksistensi Masyarakat Hukum Adat Terhadap Penguasaan Tanah Prabumian Berdasarkan Konsepsi Komunalistik Religius di Bali”, Jurnal Hukum Novelty, Volume 7

Nomor 2 Tahun 2016.

Judianto,Chusnul Tri. "Spaceborne AIS: Teknologi Satelit LAPAN-A2 Untuk Pengawasan Wilayah Maritim Indonesia”, Sosialita, Volume 11 Nomor 1 Maret 2016. 